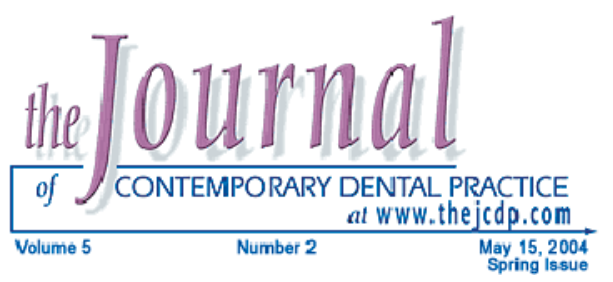

\title{
Vitamin C in Health and Disease
}

\section{Samer A. Bsoul, BDS, MS; Geza T. Terezhalmy, DDS, MA}

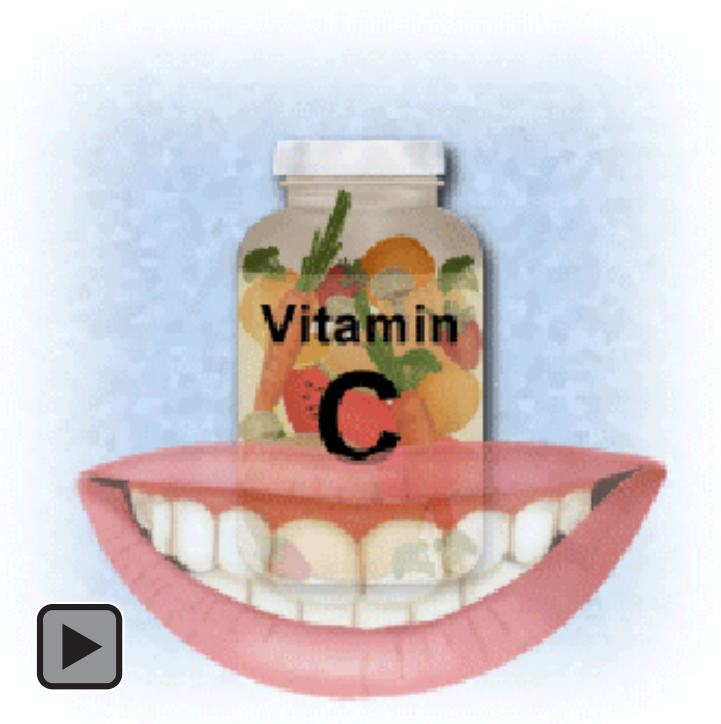

\section{Abstract}

Vitamins are essential to maintain normal metabolic processes and homeostasis within the body. The amount of a specific vitamin required by an individual varies considerably and it is influenced by such factors as body size, growth rate, physical activity, and pregnancy. Most vitamins are stored minimally in human cells, but some are stored in liver cells to a greater extent. Vitamins A and D, for example, may be stored in sufficient amounts to maintain an individual without any intake for 5 to 10 months and 2 to 4 months, respectively. However, a deficiency of vitamin B compounds (except vitamin B12) may be noted within days, and the lack of vitamin C will manifest within weeks and may result in death in 5 to 6 months. The current recommended dietary allowance (RDA) of vitamin C is $75 \mathrm{mg}$ for woman and $90 \mathrm{mg}$ for men, based on the vitamin's role as an antioxidant as well as protection from deficiency. High intakes of the vitamin are generally well tolerated, however, a Tolerable Upper Level (TUL) was recently set at $2 \mathrm{~g}$ based on gastrointestinal upset that sometimes accompanies excessive dosages. Several populations warrant special attention with respect to vitamin $\mathrm{C}$ requirements. These include patients with periodontal disease, smokers, pregnant and lactating women, and the elderly.

Keywords: Vitamin C, oral health, systemic diseases, infections, daily allowance

Citation: Bsoul SA, Terezhalmy GT. Vitamin C in Health and Disease. J Contemp Dent Pract 2004 May;(5)2:001-013.

(C) Seer Publishing 
Introduction

Humans require vitamin $\mathrm{C}$ in their diet. Fruits and vegetables are rich in vitamin $\mathrm{C}$. While prolonged storage of unprocessed fruits and vegetables leads to the loss of vitamin C, most means of food processing (boiling, steaming, freezing, canning) preserve vitamin $\mathrm{C}$ to a great extent. The intestinal absorption of vitamin

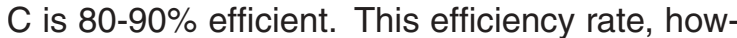
ever, declines with increased intake. Vitamin C is actively co-transported with sodium against an electrochemical gradient into intestinal (small bowel) epithelial cells. Once in the cells, a concentration gradient is created by both brush border absorption and intracellular reduction of dehydro-L-ascorbic acid (DHAA) to ascorbate. Facilitated diffusion of ascorbate into the circulation is sodium independent and follows a concentration and electrochemical gradient. A similar transport mechanism is responsible for the near complete resorption of ascorbate in the kidneys. Ascorbate and, significantly, one of its metabolites, oxalate, are found in the urine only in excess states. The latter is pertinent, as it accounts for one of the few potential clinical toxicities of systemic vitamin $\mathrm{C}$ supplementation, oxalic acid renal stones.

\section{Mechanisms of Action of Vitamin C}

Vitamin $C$ readily undergoes reversible oxidation and reduction and plays an important role as a redox agent in biological systems. ${ }^{1}$ Its best understood function is in the synthesis of collagen, which promotes the formation of hydroxyproline. ${ }^{2}$ Nonhydroxylated collagen is unstable and cannot form the triple helix required for normal structure of subcutaneous tissue, cartilage, bone, and teeth. The failure of cells to deposit collagen fibrils and intracellular cement substance leads to delayed wound healing. The inability of osteoblasts to form new bone matrix between cells prevents ossification, which may lead to bone fractures, and prevent bone healing. A lack of intracellular cement substance and an inability to form collagen fibrils results in capillary fragility characterized by petechial, purpuric, ecchymotic skin and mucosal lesions, and subperiosteal and visceral hemorrhages, which lead to anemia. ${ }^{3}$ The anemia that accompanies scurvy is of multifactorial origin. It results from acute blood loss related to hemorrhage, decreased absorption of iron, and the concurrent folate deficiency that is seen in patients with scurvy. ${ }^{4}$ Molecular studies on platelets deficient in collagen-induced aggregation also suggest a possible role for platelet-related collagen receptors. These studies have shown the platelets, which lacked collagen-induced aggregation and adhesion, have significantly reduced levels of $62-k D$ membrane glycoprotein VI (GPVI). GPVI has been suggested to function as a platelet-related collagen receptor. ${ }^{5}$ It has also been reported the serum from an idiopathic thrombocytopenic pupura patient contained an antibody against a platelet protein, which was later identified as GPVI. ${ }^{6}$

Since many foods (mushrooms, broccoli, cereals fortified with folic acid, oranges, and cataloupe) that contain vitamin $\mathrm{C}$ also contain folic acid, a diet that causes scurvy may also cause folic acid deficiency. In addition, ascorbic acid deficiency increases the oxidation of tetrahydrofolate to inactive folate metabolites and predisposes the patient to macrocytic/megaloblastic anemia. Vitamin $\mathrm{C}$ also regulates iron distribution and storage by maintaining a normal ratio of ferritin to hemosiderin. Patients with vitamin C deficiency excrete incompletely oxidized products of tyrosine, although the clinical significance of this is not clear. Vitamin $\mathrm{C}$ also appears to function as a buffer against cell damage from free radicals thought to be important in a number of disease processes. As a specific electron donor, vitamin $\mathrm{C}$ also appears to participate in the synthesis of brain neurotransmitters and pituitary peptide hormones. 
Vitamin C and Oral Health

Scurvy is the classic disease associated with vitamin $\mathrm{C}$ deficiency. The earliest symptom is fatigue followed by cutaneous findings such as follicular hyperkeratosis, perifollicular hemorrhage, bent or coiled body hair; pete-

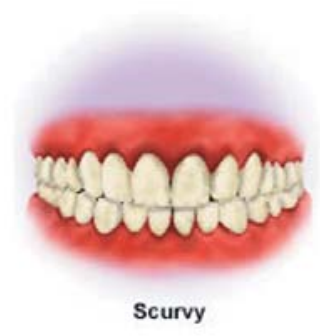
chiae, purpuras, and ecchymoses beginning on the back of the lower extremities; and xerosis. Hemorrhage into the muscles of the arms and legs and joints may lead to phlebothrombosis and pain. In severe deficiency states hemorrhage in the viscera leads to vomiting of blood and a bloody stool. In terminally scorbutic patients, syncope, cerebral hemorrhage, high fever, convulsions, shock, and death may occur abruptly. Oral manifestations of scurvy include gingival edema, bleeding, and ulcerations; secondary bacterial infections; and the loosening of teeth. ${ }^{7,8}$

\section{Periodontal Disease}

Periodontal disease is causally related to anaerobic bacteria. Tissue damage occurs as a result of complex molecular interactions between pathogenic bacteria and host immune responses. In susceptible patients, both local and systemic factors affect the pathogenesis of the infection. Vitamin C deficiency has been shown histologically to result in a lack of collagen formation by affecting the hydroxylation of proline and increasing the permeability of the oral mucosa to endotoxins. ${ }^{9}$ Vitamin $\mathrm{C}$ also enhances the mobility of polymorphonuclear leukocytes, and a deficiency of vitamin $\mathrm{C}$ is associated with decreased host immune responses. ${ }^{10,11}$ Animals placed on a diet deficient in vitamin $\mathrm{C}$ exhibit adverse changes in the periodontium related to a lack of collagen formation characterized by degenerative soft and hard tissue changes, distorted nuclear morphology of polymorphonuclear leukocytes, and reduced chemotactic responses. $^{12,13,14,15}$

Vitamin $\mathrm{C}$ has long been a candidate for modulating periodontal disease. A recent study, which evaluated the role of dietary vitamin $\mathrm{C}$ as a con- tributing factor for periodontal disease, has shown there is a relationship between reduced dietary vitamin $\mathrm{C}$ and increased risk for periodontal disease in the general population (odds ratio [OR] $=1.19 ; 95 \% \mathrm{Cl}: 1.05$ to 1.33$){ }^{16}$ The study has also shown current and former tobacco users who were taking less dietary vitamin $C$ had an increased risk of periodontal disease with an OR of $1.28,95 \% \mathrm{Cl}: 1.04$ to 1.59 for former smokers, and an OR of $1.21,95 \% \mathrm{Cl}: 1.02$ to 1.43 for current tobacco users. The dietary intake of vitamin $\mathrm{C}$ showed a weak but statistically significant relationship to periodontal disease in current and former smokers as measured by clinical attachment. Those taking the lowest levels of vitamin C, and who also smoke, are likely to show the greatest clinical effect on periodontal tissues. Since smokers already are at greater risk for periodontal disease independent of vitamin $C$ intake and oxidants from cigarette smoking lower vitamin C concentrations in blood, it can be hypothesized smokers require higher levels of dietary vitamin C intake.

\section{Dental Caries}

Ascorbic acid affects in vitro growth of bacteria and may also act in vivo to decrease caries activity. A doubleblind study has evaluated the possible association between vitamin $\mathrm{C}$ in plasma, the

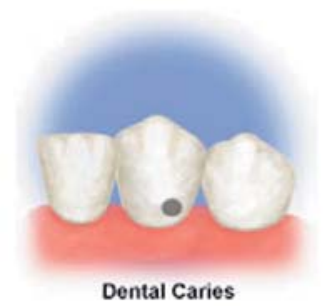
number of carious lesions, the relative numbers of selected species of the oral cariogenic flora, and the rate of salivary secretion. ${ }^{16}$ The caries status and selected bacteriological variables of dentate adult subjects with low levels of vitamin $C$ in plasma ( $<$ or $=25$ mumol/L) were compared with those of controls (plasma levels of vitamin $C>$ or $=50 \mathrm{mumol} / \mathrm{L}$ ) matched for age, sex, and number of teeth. The study concluded the amount of visible plaque and the number of decayed tooth surfaces were significantly higher in the low vitamin $\mathrm{C}$ group.

\section{Primary and Secondary Dentin Formation Collagen is the major organic matrix component of dentin. It has been shown in vitro treatment with ascorbate enhanced the formation of mineralized nodules and collagenous proteins. ${ }^{17}$ Calcium threonate may be one of the metabolites influencing the mineralization process. ${ }^{18}$ Animal}


studies have shown a mutant strain of wistar rat, characterized by hereditary lack of L-gulono-glactone oxidase, is unable to synthesize ascorbic acid when given an ascorbic acid-free diet and showed a significant reduction in both size and mineral apposition rate of dentin and a reduction in bone formation in the mandible. ${ }^{19}$ These results suggest ascorbic acid deficiency hampers dentin formation.

\section{Bone Healing}

The initial inflammatory stage of bone healing is characterized by the formation of granulation tissue and the induction of precursor cells that differentiate into fibroblasts, chondroblasts, chondroclasts, osteoblasts, osteoclasts, and cells essential for capillary proliferation. The major difference between calcifying and non-calcifying cartilage is the amount of type II and type IV collagen. In non-calcifying cartilage, type II collagen predominates because it is the major component of cartilage matrix. In calcifying cartilage, type $X$ collagen predominates under the influence of alkaline phosphatase, which is induced by ascorbate. ${ }^{20}$ In an animal study, it was found the vitamin $C$ supplemented group progressed through the various stages of bone healing faster than the control group. ${ }^{21}$ In another experimental animal study, bone healing was impaired by the presence of free oxygen radicals. ${ }^{22}$ Another benefit of vitamin $\mathrm{C}$ in bone healing may be through its antioxidant effect. Vitamin $\mathrm{C}$ deficiency has also been associated with decreased bone density in a number of animal studies. ${ }^{23,24}$ In a recent human study, low intake of vitamin $\mathrm{C}$ was found to be a risk factor for hip fractures in the elderly. ${ }^{25}$ Dietary ascorbic acid intake was independently associated with bone density among premenopausal women. Among men, serum vitamin $\mathrm{C}$ was associated in a nonlinear fashion with bone density and with self-reported fractures. Among postmenopausal women with a history of smoking and estrogen use, a standard deviation increase in plasma ascorbic acid was associated with a $49 \%$ decrease in fracture prevalence.

\section{Vitamin $\mathrm{C}$ and Cancer}

The possible anticarcinogenic effect of vitamin $\mathrm{C}$ appears to be related to its ability to detoxify carcinogens or block carcinogenic processes through its action as an antioxidant or as a freeradical scavenger. ${ }^{26}$ Other proposed mechanisms of action for vitamin $\mathrm{C}$ in the prevention and treatment of cancer include enhancement of the immune system, stimulation of collagen formation necessary for "walling off" tumors, inhibition of hyaluronidase which may keep the ground substance around the tumor intact and prevent metastasis, inhibition of oncogenic viruses, improved wound healing after cancer surgery, enhancement of the effect of certain chemotherapy drugs, reduction in the toxicity of chemotherapeutic agents such as adriamycin, prevention of free radical damage, and neutralization of carcinogenic substances. ${ }^{27,28}$ An in vitro study found an ascorbic acid and alpha-tocopherol combination inhibited human hepatoma cell proliferation, induced redifferentiation, and reversed its malignant phenotypic characteristic. ${ }^{29}$ Several studies that investigated the association between vitamin $\mathrm{C}$ and cancer suggest an inverse relationship between vitamin $C$ intake and cancers of the mouth, pharynx, esophagus, stomach, lung, and pancreas. ${ }^{30,31,32}$ A meta-analysis also found decreased breast cancer risk (20\% reduction) associated with high dietary vitamin $\mathrm{C}$ intake. ${ }^{33}$ In contrast, a recent cohort analysis showed no overall relationship with vitamin $\mathrm{C}$ intake ${ }^{34}$, and a prospective plasma study showed no association between prediagnostic vitamin $\mathrm{C}$ levels and breast cancer risk. ${ }^{35}$

\section{Cardiovascular Disease}

\section{Ischemic Heart Disease}

It has been shown oxidation of low-density lipoprotein (LDL) and lipid membranes play a crucial role in atherosclerosis. ${ }^{36}$ Although the mechanism is still unclear, it has been suggested vitamin C can protect circulating and membrane lipids from free radicals. Vitamin $C$ is also believed to protect lipids indirectly by sparing or reconstituting the active forms of vitamin $E .^{37}$ Atherosclerotic plaques impair endothelium-dependent vasodilation in human coronary and peripheral blood vessels ${ }^{36,38,39,40}$, and it has been suggested the acute administration of vitamin $\mathrm{C}$ may reverse this endothelial dysfunction. ${ }^{41,42}$ Indeed, there is emerging evidence linking high intake of vitamin $\mathrm{C}$ with

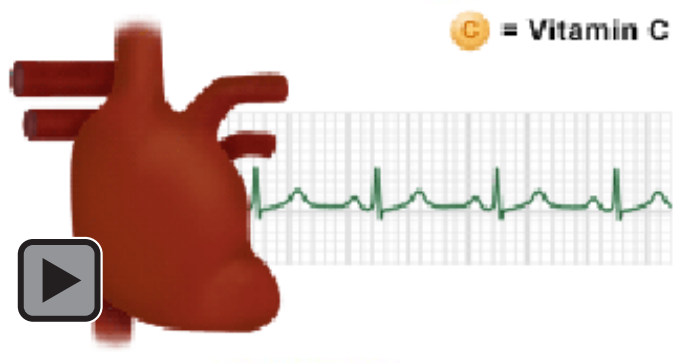


reduced mortality from heart disease. ${ }^{43,44}$ A crosssectional survey of population groups throughout Europe noted an inverse relationship between plasma levels of vitamin $\mathrm{C}$ and ischemic heart disease. ${ }^{45}$

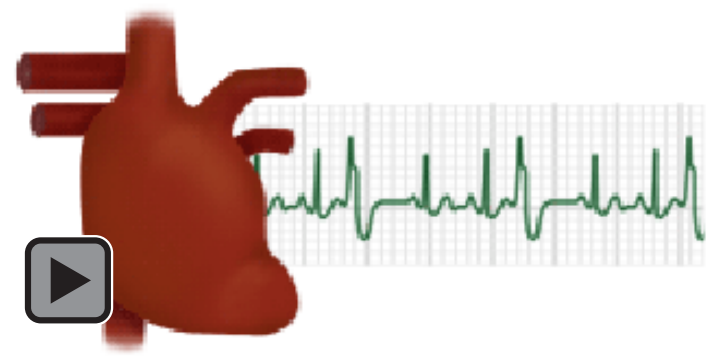

\section{Hypertension}

Nitric oxide (NO), a labile endothelial relaxing factor, is derived from L-arginine by the activity of the enzyme NO synthase. ${ }^{46}$ Essential hypertension is characterized by impaired endothelium-dependent vasodilation to specific agonists ${ }^{47,48,49,50,51}$ due to an alteration in the L-arginine-NO pathway. ${ }^{49,50,51}$ This appears to be associated with the production of superoxide anions, which impair the ability of the endothelium to induce NO-mediated relaxations of vascular smooth muscles. ${ }^{53,54,55,56}$ In patients with essential hypertension, this impaired endothelial vasodilation can be improved by the administration of vitamin $\mathrm{C}$, an effect that can be reversed by a NO synthase inhibitor. ${ }^{57}$ A cross-sectional study showed an association between higher vitamin $\mathrm{C}$ intake and lower blood pressure. ${ }^{58}$ Furthermore, vitamin $\mathrm{C}$ also appears to improve the endothelium-dependent vasomotor capacity of coronary arteries in patients with hypertension and ischemic heart disease. ${ }^{59}$

\section{Congestive Heart Failure}

Patients with congestive heart failure (CHF) demonstrate systemic vasoconstriction and reduced peripheral perfusion. While an increased sympathetic tone and an activated renin-angiotensin system have been proposed to be involved in the reduced vasodilator capacity in heart failure, clinical studies have documented endothelial dysfunction of peripheral resistance arteries ${ }^{60}$ and an impaired flow-dependent, endothelium-mediated dilation of conduit arteries. ${ }^{61}$ An important functional consequence of endothelial dysfunction is the inability of a vessel to dilate in response to endothelium-derived NO after physiological stimuli. ${ }^{62,63}$ It has been hypothesized this is caused by reduced synthesis of NO possibly due to a reduced NO-synthase gene expression. ${ }^{64}$ However, other mechanisms such as reduced availability of L-arginine or enhanced inactivation of NO by free radicals may be involved as well. ${ }^{65}$ Vitamin $\mathrm{C}$ has been shown to improve CHF by increasing the availability of nitric oxide. ${ }^{66}$ This observation suggests endothelial dysfunction in patients with CHF may be due to accelerated degradation of nitric oxide by free radicals.

\section{Vitamin C and Iron Deficiency Anemia} Iron deficiency is regarded as the major cause of nutritional anemia, but vitamins A, B12, C, E, folic acid, and riboflavin have also been linked to its development and control.

Ascorbic acid has been reported to play a key role in the absorption of dietary non-heme iron. . $^{67,68,69}$

\section{Diabetes Mellitus}

The cellular uptake of vitamin $\mathrm{C}$ is promoted by insulin and is inhibited by hyperglycemia. In the absence of insulin, hyperglycemia produces "tissue scurvy." The complications of diabetes mellitus (DM), in part, are believed to result from either the intracellular accumulation of sorbitol or the nonenzymatic glycoxidation of proteins or both. In type 1 diabetic patients, vitamin $C$ supplementation may be necessary to prevent protein glycoxidation and to optimize aldose reductase inhibition. ${ }^{70}$ Ascorbic acid status depends on the interactions of dietary vitamin C intake, plasma insulin concentrations, and glycemia. Insulin promotes the active cellular uptake of vitamin $\mathrm{C}$ whereas hyperglycemia inhibits renal vitamin $\mathrm{C}$ reabsorption. In type 1 diabetes mellitus, an adequate dietary intake of vitamin $\mathrm{C}$ is often associated with an unexpectedly low ascorbic acid status. The role of vitamin $\mathrm{C}$ as an aldose reductase inhibitor and a water soluble antioxidant in body fluids is an important adjunct to tight glycemic control. Hyperglycemia also appears to be a fundamental abnormality underlying the mechanisms that cause endothelial dysfunction in diabetic patients, which are impaired in both animal models and humans with type 1 or type 2 DM. ${ }^{71,72,73,74,75}$ Indeed, the administration of vitamin $\mathrm{C}$ has been 
shown to improve endothelium-dependent vasodilation in both experimental hyperglycemia in healthy, nondiabetic human subjects as well as in patients with either type 1 or type 2 DM. ${ }^{73,74,76,77,78}$

\section{Renal Transplantation}

Despite major advances in the management of patients with end-stage renal disease, these individuals still have a threefold higher risk of dying from ischemic heart disease (IHD) compared with age-matched healthy subjects. ${ }^{79}$ Established risk factors for IHD, such as hyperlipidemia and hypertension, remain after transplantation, and there is evidence of increased oxidative stress and enhanced low density lipoprotein oxidation in renal allograft recipients. ${ }^{80,81}$ Recent studies have also shown impaired endothelium-dependent vasodilation in patients with renal allografts independent of hypercholesterolemia, hypertension, uremia, or treatment with cyclosporine. ${ }^{82,83}$ All the above factors appear to impair endothelial function in part by increasing vascular production of superoxide anions, which may inhibit the release of nitric oxide or inactivate it directly. ${ }^{84,85}$ Vitamin C in renal transplant recipients has been shown to improve flow mediated, endothelium-dependent vasodilation and increase the resistance of lipoproteins in dilute serum to oxidation. ${ }^{86}$

\section{Age-Related Eye Diseases Degenerative eye disorders are common among the elderly. There is evidence vitamin $\mathrm{C}$ can reduce oxi- dative stress and lower the risk of such age-related degenerative changes. ${ }^{87,88}$ A prospective study in health professionals showed lower rates of self- reported cataracts among those who took multivita- min supplements or who were long-term users of vitamin $\mathrm{C}^{89}$ Another study found the 5-year risk for cataracts was $60 \%$ lower among persons who, at follow-up, reported the use of multivitamins containing vitamin $\mathrm{C}$ or $\mathrm{E}$ for more than 10 years compared to nonusers. ${ }^{90}$}

\section{Alzheimer's Disease}

There is evidence in patients with Alzheimer's disease (AD) that there is increased sensitivity of the cerebral cortex to free radicals, perhaps related to lower activity of antioxidant enzymes such as superoxide dismutase. 91,92 $^{2}$ The major targets for oxidation in the brain are lipids and lipoproteins. Supplementation with vitamin $\mathrm{E}$ and $\mathrm{C}$ significantly increases the concentrations of both vitamins in plasma and CSF and significantly decreases the in vitro oxidation of plasma lipoproteins. ${ }^{93}$ In contrast, supplementation with vitamin $\mathrm{E}$ alone did not decrease lipoprotein oxidation. Two recent studies found patients with $A D$ have low plasma vitamin $\mathrm{C}$ concentrations despite an adequate diet and supplementation with vitamin $\mathrm{C}$ may lower the risk of $A D .^{94,95}$

\section{Vitamin C and Viral Infections}

\section{The Common Cold}

The role of vitamin C in the prevention and treatment of the common cold remains controversial. A review of controlled studies suggests a reduction of at least $80 \%$ in the incidence of pneumonia in vitamin $\mathrm{C}$ groups and substantial treatment benefit from vitamin $\mathrm{C}$ in elderly patients hospitalized with pneumonia or bronchitis. ${ }^{96,97}$ It seems the preventive effects of supplementation are mainly limited to subjects with low dietary vitamin C intake, but therapeutic effects may occur in wider population groups. ${ }^{96}$ Research has shown long-term daily supplementation with large doses ( $1 \mathrm{~g}$ daily during winter months) of vitamin $\mathrm{C}$ does not appear to prevent colds, but there may be a modest benefit in reducing the duration of cold symptoms. ${ }^{98,99}$

\section{Herpetic Infections}

One study has shown the topical treatment of recurrent herpes labialis with an ascorbic acidcontaining preparation resulted in statistically significant reduction in clinical signs and symptoms. ${ }^{100}$ In another study, the efficacy of a systemic water-soluble bioflavonoid-ascorbic acid complex was evaluated in the treatment of fifty episodes of recurrent herpes labialis. ${ }^{101}$ Twenty episodes were treated with a complex of $600 \mathrm{mg}$ of water-soluble bioflavonoids and $600 \mathrm{mg}$ of ascorbic acid, administered in equal increments three times daily. Twenty episodes were treated with a complex of $1,000 \mathrm{mg}$ of water-soluble bioflavonoids and 1,000 mg of ascorbic acid, administered 
in equal increments five times daily. Ten episodes were treated with a lactose placebo. The therapeutic regimens were maintained for 3 days after the recognition of the initial symptoms associated with recurrent herpes labialis. The water-soluble bioflavonoid-ascorbic acid complex was observed to reduce vesiculation and to prevent the disruption of the vesicular membrane. The therapeutic measure was found to be the most effective when initiated during the prodromal stage of the disease process. No significant difference in the remission of symptoms was observed between the $600 \mathrm{mg}$ and the $1,000 \mathrm{mg}$ regimens, but both were statistically superior to the placebo $(p<0.01)$. Bioflavonoids maintain normal capillary permeability; ascorbic acid is known to maintain the normal mechanical strength of capillaries, to promote collagen formation, and to facilitate wound healing. Susceptible patients may benefit from the prophylactic intake of a bioflavonoid-ascorbic acid complex if initiated 24 hours prior to exposure to factors known to precipitate herpes labialis.

\section{HIV infection}

A fundamental immunologic abnormality in HIV infection is the progressive decrease and functional impairment of CD4+ lymphocytes. The functional

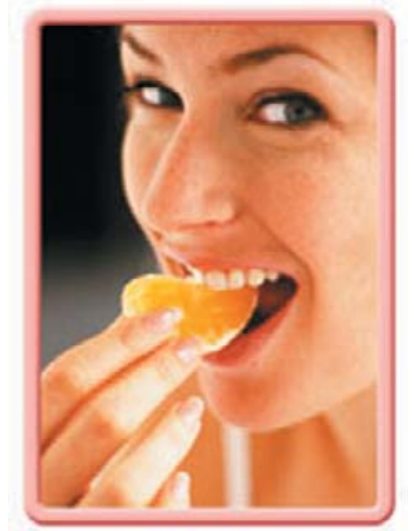

jected to therapy with non-selective non-steroidal anti-inflammatory drugs. They damage the gastric mucosa by the inhibition of protective prostaglandins on mucosal tissues. This results in microvascular injury accompanied by the activation of neutrophils and the release of oxygen radicals. ${ }^{113}$ Vitamin C was found to eliminate free radicals. ${ }^{114}$ Vitamin $C$ is also potentially important in the prevention of gastric cancer by scavenging nitrate and preventing the nitrosation of dietary substances by potentially carcinogenic $\mathrm{N}$-nitrosoamines. ${ }^{115}$

\section{Recommended Daily Allowances of Vitamin C} The current daily recommended dietary allowance (RDA) of vitamin $\mathrm{C}$ is $75 \mathrm{mg}$ for women and $90 \mathrm{mg}$ for men, based on the vitamin's role as an antioxidant as well as protection from deficiency. ${ }^{116,117}$ Pharmacological doses (>100 mg/ day) of vitamin $\mathrm{C}$ may reduce the risk of chronic diseases such as cancer, cardiovascular disease, and cataracts, probably through antioxidant mechanisms. The totality of the reviewed data suggests vitamin $\mathrm{C}$, $100 \mathrm{mg} /$ day, may be required for the optimum reduction of chronic disease risks in nonsmoking men and women. ${ }^{118}$ Several populations warrant special attention with respect to capacity of lymphocytes is critically dependent on intracellular redox balance and oxidative stress. An inability of antioxidants to neutralize the formation of reactive oxygen species has been shown to impair lymphocyte functions. ${ }^{102,103}$ Glutathion, a cysteine-containing tripeptide, is the dominant intracellular antioxidant. ${ }^{104}$ Several reports have suggested decreased antioxidant defense due to disturbed glutathione homeostasis plays a role in the immunopathogenesis of HIV infection. ${ }^{105,106,107}$ Antioxidants such as $\mathrm{N}$-acetyl cysteine, glutathione, glutathione-esters, and vitamin $\mathrm{C}$ have been demonstrated to inhibit HIV replication in vitro and several of these antioxidants appear to have cooperative interactions. ${ }^{108-111}$ In vivo, vitamin C and $E$ have been shown to reduce oxidative stress in HIV infected patients and to reduce the viral load. ${ }^{112}$

Vitamin C and The Gastrointestinal System Gastrointestinal ulcers, erosions, and bleeding are common adverse reactions in patients sub- vitamin $\mathrm{C}$ requirements. These include patients with periodontal disease, smokers, pregnant and lactating women, and the elderly.

\section{Patients with Periodontal Disease}

Based on evidence from a recent study, it can be concluded there is a significant relationship between dietary vitamin $\mathrm{C}$ intake and periodontal disease after adjusting for age, gender, gingival bleeding, and tobacco consumption. ${ }^{16}$ When compared to patients taking in excess of 180 $\mathrm{mg}$ of dietary vitamin $\mathrm{C}$ daily, the odds ratios for periodontal disease were 1.30, 1.26, 1.21, and 1.16 for patients taking 0-29 mg, 30-59 mg, 60-99 $\mathrm{mg}$, and $100-179 \mathrm{mg}$ of vitamin C, respectively. These findings indicate there is a dose-dependent relationship between dietary vitamin $C$ intake and periodontal disease. Therefore, patients with periodontal disease may benefit from a dietary analysis and, when appropriate, from daily vitamin C supplementation. 


\section{Smokers}

Smokers have a higher requirement for vitamin C than nonsmokers. ${ }^{119,120}$ Vitamin C concentrations in smokers are inversely related to cigarette consumption. ${ }^{121-124}$ This is most likely due to increased demand as a result of increased oxidative stress. ${ }^{121,122,124}$ In one study, vitamin C supplementation ( $2000 \mathrm{mg} /$ day for 5 days) significantly reduced the amount of urinary F2-isoprostanes, an indicator of oxidative stress. ${ }^{125}$ The current RDA for smokers is $110 \mathrm{mg} /$ day for women and $125 \mathrm{mg} /$ day for men ${ }^{117}$, although it has been proposed smokers require 120 to $180 \mathrm{mg} /$ day to maintain plasma vitamin $\mathrm{C}$ concentrations comparable to nonsmokers. ${ }^{125}$

\section{Pregnant and Lactating Women}

Pregnant or lactating women also require a higher intake of vitamin $\mathrm{C}$ to maintain optimal plasma vitamin $C$ concentrations. ${ }^{120,126}$ The higher requirement is due to active placental vitamin $C$ transport, whereby vitamin $C$ concentrations are significantly higher in cord blood and in newborn infants than in the mothers, and the loss of vitamin $C$ through milk. ${ }^{120,127}$ The current RDA for women during pregnancy and lactation is 85 and $120 \mathrm{mg} /$ day, respectively. ${ }^{117}$

\section{The Elderly}

The elderly are prone to vitamin C deficiency because of dietary habits. ${ }^{120,119,126}$ They also appear to have a higher requirement for vitamin $\mathrm{C}$, although the evidence is inconsistent. ${ }^{126}$ The RDA for those over 70 years of age is the same as for young adults $(75 \mathrm{mg}$ for women and 90 $\mathrm{mg}$ for men). ${ }^{117}$ Oxidative processes have been implicated in aging and it has been proposed antioxidants may have beneficial effects on cognitive functions in the elderly. ${ }^{128}$ In one cross-sectional study there was no association between cognitive function and intake of vitamin C (>160 mg/day compared with $<70 \mathrm{mg} /$ day). ${ }^{129}$ However, two other studies have shown high plasma vitamin C concentrations lower the prevalence of severe cognitive impairment. ${ }^{130,131}$
Vitamin C Toxicity

Vitamin $\mathrm{C}$ appears to be relatively nontoxic, although intake levels above $1 \mathrm{gram} /$ day can cause nausea and diarrhea. ${ }^{11,132}$ The tolerable upper intake level for adults is $2000 \mathrm{mg} .{ }^{117}$ Potential problems with pharmacological doses may also include "rebound scurvy," which occurs when the intake of high levels is abruptly stopped. In excess states ( $>4$ gram/day), high levels of ascorbate and, significantly, one of its metabolites, oxalate, are found in urine and may increase the risk of renal-oxalate stone formation. The latter is pertinent, as it accounts for one of the few potential clinical toxicities of systemic vitamin C supplementation.

\section{Summary}

The current RDA of vitamin $\mathrm{C}$ for nonsmoking women and men is $75 \mathrm{mg}$ and $90 \mathrm{mg}$, respectively. The totality of the reviewed data suggests these dosages of vitamin $\mathrm{C}$ are optimal in this population both as an essential nutrient as well as an effective antioxidant. Several populations warrant special attention with respect to vitamin $C$ requirements. These include patients with periodontal disease, smokers, pregnant and lactating women, and the elderly. However, even in these subpopulations, the data do not support recommending the routine daily intake of more than $200 \mathrm{mg}$ of vitamin C. While higher dosages are generally well tolerated, the tolerable upper level of vitamin $C$ is $2 \mathrm{~g}$. In response to the aggressive promotion and advertising by health food advocates related to the use of nutritional supplements and antioxidant, patients may seek information from their dentist, a trusted source, about holistic issues. Clinicians should be cognizant about such issues and should be prepared to provide their patients with evidence-based recommendations. In their comprehensive approach to patient care, clinicians should base the need for recommending dosages in excess of the RDA on sound data supported by a nutritional analysis and the patients' plasma vitamin $\mathrm{C}$ concentration (normal: $>0.2 \mathrm{mg} / \mathrm{dl}$ ) levels.

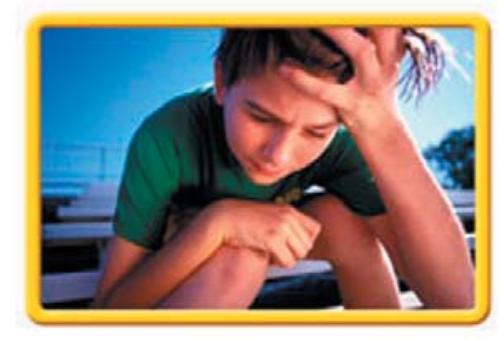




\section{References}

1. Kuroyanagi M, Shimamura E, Kim M, et. al. Effects of L-ascorbic acid on lysyl oxidase in the formation of collagen cross-links. Biosci Biotechnol Biochem. 2002 Oct;66(10):2077-82.

2. B. Peterkovsky. Ascorbate requirements for hydroxylation and secretion of procollagen: relation to inhibition of collagen synthesis in scurvy. Am J Clin Nutr 54 Suppl (1991), pp. 35S-40S.

3. Leung FW, Guze PA. Adult scurvy. Ann Emerg Med. 1981 Dec;10(12):652-5.

4. Oeffinger KC. Scurvy: more than historical relevance. Am Fam Physician. 1993 Sep 15;48(4):609-13. Review.

5. Moroi M, Jung SM, Okuma M, et. al. A patient with platelets deficient in glycoprotein VI that lack both collagen-induced aggregation and adhesion. J Clin Invest. 1989 Nov;84(5):1440-5.

6. Sugiyama T, Okuma M, Ushikubi $F$, et. al. A novel platelet aggregating factor found in a patient with defective collagen-induced platelet aggregation and autoimmune thrombocytopenia. Blood. 1987 Jun;69(6):1712-20.

7. Lowe G, Woodward M, Rumley A, et. al. Total tooth loss and prevalent cardiovascular disease in men and women: possible roles of citrus fruit consumption, vitamin $\mathrm{C}$, and inflammatory and thrombotic variables. J Clin Epidemiol. 2003 Jul;56(7):694-700.

8. Marshall R. Oral lesions in scurvy. Aust Dent J. 2002 Mar;47(1):82; author reply 82-3. No abstract available.

9. Alfano MC, Miller SA, Drummond JF. Effect of ascorbic acid deficiency on the permeability and collagen biosynthesis of oral mucosal epithelium. Ann NY Acad Sci. 1975 Sep 30;258:253-63. No abstract available.

10. Goetzl EJ, Wasserman SI, Gigli I, et. al. Enhancement of random migration and chemotactic response of human leukocytes by ascorbic acid. J Clin Invest. 1974 Mar;53(3):813-8. No abstract available.

11. Sandler JA, Gallin JI, Vaughan M. Effects of serotonin, carbamylcholine, and ascorbic acid on leukocyte cyclic GMP and chemotaxis. J Cell Biol. 1975 Nov;67(2PT.1):480-4.

12. Alvares $\mathrm{O}$, Siegel I. Permeability of gingival sulcular epithelium in the development of scorbutic gingivitis. J Oral Pathol. 1981 Feb;10(1):40-8.

13. Alvares O, Altman LC, Springmeyer S, et. al. The effect of subclinical ascorbate deficiency on periodontal health in nonhuman primates. J Periodontal Res. 1981 Nov;16(6):628-36. No abstract available.

14. Hunt AM, Paynter KJ. The effects of ascorbic acid deficiency on the teeth and periodontal tissues of guinea pigs. J Dent Res. 1959 Mar-Apr;38(2):232-43. No abstract available.

15. Goldshmidt MC. Reduced bactericidal activity in neutrophils from scorbutic animals and the effect of ascorbic acid on these target bacteria in vivo and in vitro. Am J Clin Nutr. 1991 Dec;54(6 Suppl): 1214S-1220S.

16. Nishida M, Grossi SG, Dunford RG, et. al. Dietary vitamin C and the risk for periodontal disease. J Periodontol. 2000 Aug;71(8):1215-23.

17. Vaananen MK, Markkanen HA, Tuovinen VJ, et. al. Dental caries and mutans streptococci in relation to plasma ascorbic acid. Scand J Dent Res. 1994 Apr;102(2):103-8.

18. Rowe DJ, Ko S, Tom XM, et. al. Enhanced production of mineralized nodules and collagenous proteins in vitro by calcium ascorbate supplemented with vitamin C metabolites. J Periodontol. 1999 Sep;70(9):992-9.

19. Ogawara M, Aoki K, Okiji T, et. al. Effect of ascorbic acid deficiency on primary and reparative dentinogenesis in non-ascorbate-synthesizing ODS rats. Arch Oral Biol. 1997 Oct-Nov;42(10-11):695-704.

20. Sullivan TA, Uschmann B, Hough R, et. al. Ascorbate modulation of chondrocyte gene expression is independent of its role in collagen secretion. J Biol Chem. 1994 Sep 9;269(36):22500-6.

21. Yilmaz $\mathrm{C}$, Erdemli $\mathrm{E}$, Selek $\mathrm{H}$, et. al. The contribution of vitamin $\mathrm{C}$ to healing of experimental fractures. Arch Orthop Trauma Surg. 2001 Jul;121(7):426-8.

22. Gokturk E, Turgut A, Baycu C, et. al. Oxygen-free radicals impair fracture healing in rats. Acta Orthop Scand. 1995 Oct;66(5):473-5.

23. Kipp DE, Grey CE, McElvain ME, et. al. Long-term low ascorbic acid intake reduces bone mass in guinea pigs. J Nutr. 1996 Aug;126(8):2044-9. 
24. Kipp DE, McElvain M, Kimmel DB, et. al. Scurvy results in decreased collagen synthesis and bone density in the guinea pig animal model. Bone. 1996 Mar;18(3):281-8. Erratum in: Bone 1996 Oct;19(4):419.

25. Simon JA, Hudes ES, Tice JA. Relation of serum ascorbic acid to mortality among US adults. J Am Coll Nutr. 2001 Jun;20(3):255-63.

26. Rock CL, Jacob RA, Bowen PE. Update on the biological characteristics of the antioxidant micronutrients: vitamin C, vitamin E, and the carotenoids. J Am Diet Assoc. 1996 Jul;96(7):693-702; quiz 703-4. Review.

27. Bendich A, Machlin LJ, Scandurra O. The antioxidant role of vitamin C. Adv Free Rad Biol Med 1986;2:419.

28. Head KA. Ascorbic acid in the prevention and treatment of cancer. Altern Med Rev. 1998 Jun;3(3): 174-86. Review.

29. Kang JH, Shi YM, Zheng RL. Effects of ascorbic acid and DL-alpha-tocopherol on human hepatoma cell proliferation and redifferentiation. Acta Pharmacol Sin. 2000 Apr;21(4):348-52.

30. Negri E, Franceschi S, Bosetti C, et. al. Selected micronutrients and oral and pharyngeal cancer. Int J Cancer. 2000 Apr 1;86(1):122-7.

31. You WC, Zhang L, Gail MH, et. al. Gastric dysplasia and gastric cancer: Helicobacter pylori, serum vitamin C, and other risk factors. J Natl Cancer Inst. 2000 Oct 4;92(19):1607-12.

32. Freudenheim JL, Marshall JR, Vena JE, et. al. Premenopausal breast cancer risk and intake of vegetables, fruits, and related nutrients. J Natl Cancer Inst. 1996 Mar 20;88(6):340-8.

33. Gandini S, Merzenich H, Robertson C, et. al. Meta-analysis of studies on breast cancer risk and diet: the role of fruit and vegetable consumption and the intake of associated micronutrients. Eur $\mathrm{J}$ Cancer. 2000 Mar;36(5):636-46.

34. Michels KB, Holmberg L, Bergkvist L, et. al. Dietary antioxidant vitamins, retinol, and breast cancer incidence in a cohort of Swedish women. Int J Cancer. 2001 Feb 15;91(4):563-7.

35. Wu K, Helzlsouer KJ, Alberg AJ, et. al. A prospective study of plasma ascorbic acid concentrations and breast cancer (United States). Cancer Causes Control. 2000 Mar;11(3):279-83.

36. Anderson TJ, Meredith IT, Yeung AC, et. al. The effect of cholesterol-lowering and antioxidant therapy on endothelium-dependent coronary vasomotion. N Engl J Med. 1995 Feb 23;332(8):488-93.

37. Tappel AL. Vitamin E as the biological lipid antioxidant. Vitam Horm 1962;20:493.

38. Zeiher AM, Drexler $\mathrm{H}$, Wollschlager $\mathrm{H}$, et. al. Modulation of coronary vasomotor tone in humans. Progressive endothelial dysfunction with different early stages of coronary atherosclerosis. Circulation. 1991 Feb;83(2):391-401.

39. Creager MA, Cooke JP, Mendelsohn ME, et. al. Impaired vasodilation of forearm resistance vessels in hypercholesterolemic humans. J Clin Invest. 1990 Jul;86(1):228-34.

40. Casino PR, Kilcoyne CM, Quyyumi AA, et. al. The role of nitric oxide in endothelium-dependent vasodilation of hypercholesterolemic patients. Circulation. 1993 Dec;88(6):2541-7.

41. Ting HH, Timimi FK, Haley EA, et. al. Vitamin C improves endothelium-dependent vasodilation in forearm resistance vessels of humans with hypercholesterolemia. Circulation. 1997 Jun 17;95(12):261722.

42. Hamabe A, Takase B, Uehata A, et. al. Impaired endothelium-dependent vasodilation in the brachial artery in variant angina pectoris and the effect of intravenous administration of vitamin $\mathrm{C}$. Am J Cardiol. 2001 May 15;87(10):1154-9.

43. Enstrom JE, Kanim LE, Klein MA. Vitamin C intake and mortality among a sample of the United States population. Epidemiology. 1992 May;3(3):194-202.

44. Sahyoun NR, Jacques PF, Russell RM. Carotenoids, vitamins $C$ and E, and mortality in an elderly population. Am J Epidemiol. 1996 Sep 1;144(5):501-11.

45. Gey KF, Brubacher GB, Stahelin HB. Plasma levels of antioxidant vitamins in relation to ischemic heart disease and cancer. Am J Clin Nutr. 1987 May;45(5 Suppl):1368-77. No abstract available.

46. Palmer RM, Ashton DS, Moncada S. Vascular endothelial cells synthesize nitric oxide from L-arginine. Nature. 1988 Jun 16;333(6174):664-6.

47. Panza JA, Quyyumi AA, Brush JE Jr, et. al. Abnormal endothelium-dependent vascular relaxation in patients with essential hypertension. N Engl J Med. 1990 Jul 5;323(1):22-7. 
48. Taddei S, Virdis A, Mattei P, et. al. Vasodilation to acetylcholine in primary and secondary forms of human hypertension. Hypertension. 1993 Jun;21(6 Pt 2):929-33.

49. Panza JA, Casino PR, Kilcoyne CM, et. al. Role of endothelium-derived nitric oxide in the abnormal endothelium-dependent vascular relaxation of patients with essential hypertension. Circulation. 1993 May;87(5):1468-74.

50. Panza JA, Casino PR, Badar DM, et. al. Effect of increased availability of endothelium-derived nitric oxide precursor on endothelium-dependent vascular relaxation in normal subjects and in patients with essential hypertension. Circulation. 1993 May;87(5):1475-81.

51. Panza JA, Casino PR, Kilcoyne CM, et. al. Impaired endothelium-dependent vasodilation in patients with essential hypertension: evidence that the abnormality is not at the muscarinic receptor level. $J$ Am Coll Cardiol. 1994 Jun;23(7):1610-6.

52. Taddei S, Virdis A, Ghiadoni L, et. al. Cyclooxygenase inhibition restores nitric oxide activity in essential hypertension. Hypertension. 1997 Jan;29(1 Pt 2):274-9.

53. Kontos HA, Kontos MC. Role of products of univalent reduction of oxygen in hypertensive vascular injury. In:Laragh JH, Brenner,BM, eds. Hypertension: Pathophysiology. Diagnosis, and Management. 2nd ed. New York, NY: Raven Press, Ltd: 1995;685-696.

54. Mugge A, Elwell JH, Peterson TE, et. al. Release of intact endothelium-derived relaxing factor depends on endothelial superoxide dismutase activity. Am J Physiol. 1991 Feb;260(2 Pt 1):C219-25.

55. Sunman W, Hughes Ad, Sever PS. Free-radical scavengers, thiol-containing reagents and endothelium-dependent relaxation in isolated rat and human resistance arteries. Clin Sci (Lond). 1993 Mar;84(3):287-95.

56. Grunfeld S, Hamilton CA, Mesaros S, et. al. Role of superoxide in the depressed nitric oxide production by the endothelium of genetically hypertensive rats. Hypertension. $1995 \mathrm{Dec} ; 26(6 \mathrm{Pt} \mathrm{1}): 854-7$.

57. Taddei S, Virdis A, Ghiadoni A, et. al. Vitamin C improves endothelium-dependent vasodilation by restoring nitric oxide activity in essential hypertension. Circulation. 1998 Jun 9;97(22):2222-9.

58. Ness AR, Chee D, Elliott P. Vitamin C and blood pressure--an overview. J Hum Hypertens. 1997 Jun;11(6):343-50. Review.

59. Solzbach U, Hornig B, Jeserich M, et. al. Vitamin C improves endothelial dysfunction of epicardial coronary arteries in hypertensive patients. Circulation. 1997 Sep 2;96(5):1513-9.

60. Drexler H, Hayoz D, Münzel T, et. al. Endothelial function in chronic congestive heart failure. Am J Cardiol. 1992 Jun 15;69(19):1596-601.

61. Hayoz D, Drexler H, Münzel T, et. al. Flow-mediated arteriolar dilation is abnormal in congestive heart failure. Circulation. 1993;87(suppI VII):VII-92-VII-96.

62. Drexler $\mathrm{H}$, Zeiher $\mathrm{A}$, Wollschläger $\mathrm{H}$, et. al. Flow-dependent coronary artery dilatation in humans. Circulation. 1989 Sep;80(3):466-74.

63. Hornig B, Maier V, Drexler H. Physical training improves endothelial function in patients with chronic heart failure. Circulation. 1996 Jan 15;93(2):210-4.

64. Smith CJ, Sun D, Hoegler C, et. al. Reduced gene expression of vascular endothelial NO synthase and cyclooxygenase-1 in heart failure. Circ Res. 1996 Jan;78(1):58-64.

65. Belch JJF, Bridges $A B$, Scott $N$, et. al. Oxygen free radicals and congestive heart failure. Br Heart J. 1991 May;65(5):245-8.

66. Hornig B, Arakawa N, Kohler C, et. al. Vitamin C improves endothelial function of conduit arteries in patients with chronic heart failure. Circulation. 1998 Feb 3;97(4):363-8.

67. Hallberg L. Iron and vitamins. Bibl Nutr Dieta. 1995;(52):20-9. Review.

68. Sharma DC, Mathur R. Correction of anemia and iron deficiency in vegetarians by administration of ascorbic acid. Indian J Physiol Pharmacol. 1995 Oct;39(4):403-6.

69. Mao X, Yao G. Effect of vitamin C supplementations on iron deficiency anemia in Chinese children. Biomed Environ Sci. 1992 Jun;5(2):125-9.

70. Cunningham JJ. The glucose/insulin system and vitamin C: implications in insulin-dependent diabetes mellitus. J Am Coll Nutr. 1998 Apr;17(2):105-8. Review.

71. Vane JR, Anggard EE, Botting RM. Regulatory functions of the vascular endothelium. N Engl J Med. 1990 Jul 5;323(1):27-36. Review. No abstract available.

72. Pieper GM, Gross GJ. Oxygen free radicals abolish endothelium-dependent relaxation in diabetic rat aorta. Am J Physiol. 1988 Oct;255(4 Pt 2):H825-33. 
73. Timimi FK, Ting HH, Haley EA, et. al. Vitamin $\mathrm{C}$ improves endothelium-dependent vasodilation in patients with insulin-dependent diabetes mellitus. J Am Coll Cardiol. 1998 Mar 1;31(3):552-7.

74. Ting HH, Timimi FK, Boles KS, et. al. Vitamin $\mathrm{C}$ improves endothelium-dependent vasodilation in patients with non-insulin-dependent diabetes mellitus. J Clin Invest. 1996 Jan 1;97(1):22-8.

75. Kawano H, Motoyama $\mathrm{T}$, Hirashima $\mathrm{O}$, et. al. Hyperglycemia rapidly suppresses flow-mediated endothelium-dependent vasodilation of brachial artery. J Am Coll Cardiol. 1999 Jul;34(1):146-54.

76. Rubanyi GM, Vanhoutte PM. Oxygen-derived free radicals, endothelium, and responsiveness of vascular smooth muscle. Am J Physiol. 1986 May;250(5 Pt 2):H815-21.

77. Beckman JS, Beckman TW, Chen J, et. al. Apparent hydroxyl radical production by peroxynitrite: implications for endothelial injury from nitric oxide and superoxide. Proc Natl Acad Sci U S A. 1990 Feb;87(4):1620-4.

78. Beckman JA, Goldfine AB, Gordon MB, et. al. Ascorbate restores endothelium-dependent vasodilation impaired by acute hyperglycemia in humans. Circulation. 2001 Mar 27;103(12):1618-23.

79. US Renal Data System US RDS 1991 Annual Data Report. The National Institute of Health, National Institute of Diabetes and Digestive and Kidney Diseases, Bethesda, MD; 1991.

80. Taylor JE, Scott N, Hill A, et. al. Oxygen free radicals and platelet and granulocyte aggregability in renal transplant patients. Transplantation. 1993 Mar;55(3):500-4.

81. Sutherland $\mathrm{WH}$, Walker RJ, Ball MJ, et. al. Oxidation of low density lipoproteins from patients with renal failure or renal transplants. Kidney Int. 1995 Jul;48(1):227-36.

82. Hausberg M, Kisters $\mathrm{K}$, Kosch $\mathrm{M}$, et. al. Flow-mediated vasodilation and distensibility of the brachial artery in renal allograft recipients. Kidney Int. 1999 Mar;55(3):1104-10.

83. Morris ST, McMurray JJ, Rodger RS, et. al. Endothelial dysfunction in renal transplant recipients maintained on cyclosporine. Kidney Int. 2000 Mar;57(3):1100-6.

84. Ohara Y, Peterson TE, Harrison DG. Hypercholesterolemia increases endothelial superoxide anion production. J Clin Invest. 1993 Jun;91(6):2546-51.

85. Diaz MN, Frei B, Vita JA, et. al. Antioxidants and atherosclerotic heart disease. N Engl J Med. 1997 Aug 7;337(6):408-16. Review.

86. Williams MJ, Sutherland WH, McCormick MP, et. al. Vitamin C improves endothelial dysfunction in renal allograft recipients. Nephrol Dial Transplant. 2001 Jun;16(6):1251-5.

87. Taylor A, Jacques PF, Epstein EM. Relations among aging, antioxidant status, and cataract. Am J Clin Nutr. 1995 Dec;62(6 Suppl):1439S-1447S. Review.

88. Snodderly DM. Evidence for protection against age-related macular degeneration by carotenoids and antioxidant vitamins. Am J Clin Nutr. 1995 Dec;62(6 Suppl):1448S-1461S. Review.

89. Hankinson SE, Stampfer MJ, Seddon JM, et. al. Nutrient intake and cataract extraction in women: a prospective study. BMJ. 1992 Aug 8;305(6849):335-9.

90. Mares-Perlman JA, Lyle BJ, Klein R, et. al. Vandenlangenberg GM, Trabulsi JN, Palta M. Vitamin supplement use and incident cataracts in a population-based study. Arch Ophthalmol. 2000 Nov;118(11): 1556-63.

91. Richardson SJ. Free radicals in the genesis of Alzheimer's disease. Ann N Y Acad Sci. 1993 Sep 24;695:73-6.

92. Thome J, Gsell W, Rosler M, et. al. Oxidative-stress associated parameters (lactoferrin, superoxide dismutases) in serum of patients with Alzheimer's disease. Life Sci. 1997;60(1):13-9.

93. Kontush A, Mann U, Arlt S, et. al. Influence of vitamin E and C supplementation on lipoprotein oxidation in patients with Alzheimer's disease. Free Radic Biol Med. 2001 Aug 1;31(3):345-54.

94. Riviere S, Birlouez-Aragon I, Nourhashemi F, et. al. Low plasma vitamin C in Alzheimer patients despite an adequate diet. Int J Geriatr Psychiatry 1998;13:749-54.

95. Morris MC, Beckett LA, Scherr PA, et. al. Vitamin E and vitamin C supplement use and risk of incident Alzheimer disease. Alzheimer Dis Assoc Disord. 1998 Sep;12(3):121-6.

96. Hemila H, Douglas RM. Vitamin C and acute respiratory infections. Int J Tuberc Lung Dis. 1999 Sep;3(9):756-61. Review.

97. Hunt C, Chakravorty NK, Annan G, et. al. The clinical effects of vitamin C supplementation in elderly hospitalised patients with acute respiratory infections. Int J Vitam Nutr Res. 1994;64(3):212-9.

98. Douglas RM, Chalker EB, Treacy B. Vitamin C for preventing and treating the common cold. Cochrane Database Syst Rev. 2000;(2):CD000980. Review. 
99. Van Straten M, Josling P. Preventing the common cold with a vitamin C supplement: a double-blind, placebo-controlled survey. Adv Ther. 2002 May-Jun;19(3):151-9.

100. Hovi T, Hirvimies A, Stenvik M, et. al. Topical treatment of recurrent mucocutaneous herpes with ascorbic acid-containing solution. Antiviral Res. 1995 Jun;27(3):263-70.

101. Terezhalmy GT, Bottomley WK, Pelleu GB. The use of water-soluble bioflavonoid-ascorbic acid complex in the treatment of recurrent herpes labialis. Oral Surg Oral Med Oral Pathol. 1978 Jan;45(1): 56-62.

102. Hamilos DL, Wedner HJ. The role of glutathione in lymphocyte activation. I. Comparison of inhibitory effects of buthionine sulfoximine and 2-cyclohexene-1-one by nuclear size transformation. $\mathrm{J}$ Immunol. 1985 Oct;135(4):2740-7.

103. Yamauchi A, Bloom ET. Requirement of thiol compounds as reducing agents for IL-2-mediated induction of LAK activity and proliferation of human NK cells. J Immunol. 1993 Nov 15;151(10):5535-44.

104. Müller F, Aukrust $P$, Svardal AM, et. al. The thiols glutathione, cysteine, and homocysteine in human immunodeficiency virus (HIV) infection. In: Watson RR. editor. Nutrients and Foods in AIDS. Boca Raton: CRC Press. 1998: 35-69.

105. Staal FJ, Roederer M, Israelski DM, et. al. Intracellular glutathione levels in T cell subsets decrease in HIV-infected individuals. AIDS Res Hum Retroviruses. 1992 Feb;8(2):305-11.

106. Roederer M, Staal FJ, Osada H, et. al. CD4 and CD8 T cells with high intracellular glutathione levels are selectively lost as the HIV infection progresses. Int Immunol. 1991 Sep;3(9):933-7.

107. Aukrust P, Svardal AM, Müller F. Increased levels of oxidized glutathione in CD4+ lymphocytes associated with disturbed intracellular redox balance in human immunodeficiency virus type 1 infection. Blood. 1995 Jul 1;86(1):258-67.

108. Kalebic T, Kinter A, Poli G, et. al. Suppression of human immunodeficiency virus expression in chronically infected monocytic cells by glutathione, glutathione ester, and $\mathrm{N}$-acetylcysteine. Proc Natl Acad Sci U S A. 1991 Feb 1;88(3):986-90.

109. Harakeh S, Jariwalla RJ. Comparative study of the anti-HIV activities of ascorbate and thiol-containing reducing agents in chronically HIV-infected cells. Am J Clin Nutr. 1991 Dec;54(6 Suppl):1231S$1235 S$.

110. Rawal BD, Bartolini F, Vyas GN. In vitro inactivation of human immunodeficiency virus by ascorbic acid. Biologicals. 1995 Mar;23(1):75-81.

111. Muller F, Svardal AM, Nordoy I, et. al. Virological and immunological effects of antioxidant treatment in patients with HIV infection. Eur J Clin Invest. 2000 Oct;30(10):905-14.

112. Allard JP, Aghdassi E, Chau J, et. al. Effects of vitamin $E$ and $C$ supplementation on oxidative stress and viral load in HIV-infected subjects. AIDS. 1998 Sep 10;12(13):1653-9.

113. Seager JM, Hawkey CJ. NSAID gastropathy. In: Bianchi Porro G, ed. Gastroenterology and Hepatology. London: McGraw-Hill, 1999: 181-92.

114. Pohle T, Brzozowski T, Becker JC, et. al. Role of reactive oxygen metabolites in aspirin-induced gastric damage in humans: gastroprotection by vitamin C. Aliment Pharmacol Ther. 2001 May;15(5):67787.

115. Mirvish SS. Role of N-nitroso compounds (NOC) and N-nitrosation in etiology of gastric, esophageal, nasopharyngeal and bladder cancer and contribution to cancer of known exposures to NOC. Cancer Lett. 1995 Jun 29;93(1):17-48. Review. Erratum in: Cancer Lett 1995 Nov 6;97(2):271.

116. Jacob RA, Sotoudeh G. Vitamin C function and status in chronic disease. Nutr Clin Care. 2002 MarApr;5(2):66-74. Review.

117. Standing Committee on the Scientific Evaluation of Dietary Reference Intakes, Food and Nutrition Board. Dietary Reference Intakes for Vitamin C, Vitamin E, Selenium, and Beta-carotene, and Other Carotenoids. Washington, DC: National Academy Press; 2000.

118. Carr AC, Frei B. Toward a new recommended dietary allowance for vitamin $C$ based on antioxidant and health effects in humans. Am J Clin Nutr. 1999 Jun;69(6):1086-107. Review.

119. Weber $P$, Bendich $A$, Schalch W. Vitamin $C$ and human health--a review of recent data relevant to human requirements. Int J Vitam Nutr Res. 1996;66(1):19-30. Review.

120. Burri BJ, Jacob RA. Human metabolism and the requirement for vitamin C. In: Packer L, Fuchs J, eds. Vitamin C in health and disease. New York: Marcel Dekker Inc, 1997:341-66.

13

The Journal of Contemporary Dental Practice, Volume 5, No. 2, May 15, 2004 
121. Jarvinen R, Knekt P. Vitamin C, smoking, and alcohol consumption. In: Packer L, Fuchs J, eds. Vitamin C in health and disease. New York: Marcel Dekker Inc, 1997:425-55.

122. Cross CE, Halliwell B. Nutrition and human disease: how much extra vitamin $C$ might smokers need? Lancet 1993;341:1091 (letter).

123. Lykkesfeldt J, Prieme H, Loft S, et. al. Effect of smoking cessation on plasma ascorbic acid concentration. BMJ 1996;313:91.

124. Lykkesfeldt J, Loft S, Nielsen JB, et. al. Ascorbic acid and dehydroascorbic acid as biomarkers of oxidative stress caused by smoking. Am J Clin Nutr. 1997 Apr;65(4):959-63.

125. Reilly M, Delanty N, Lawson JA, et. al. Modulation of oxidant stress in vivo in chronic cigarette smokers. Circulation. 1996 Jul 1;94(1):19-25.

126. Plodin NW. Vitamin C. In: Pharmacology of micronutrients. New York: Alan R Liss Inc, 1988:201-44.

127. Berger TM, Rifai N, Avery ME, et. al. Vitamin C in premature and full-term human neonates. Redox Rep 1996;2:257-62.

128. Ames BN, Shigenaga MK, Hagen TM. Oxidants, antioxidants, and the degenerative diseases of aging. Proc Natl Acad Sci U S A. 1993 Sep 1;90(17):7915-22. Review.

129. Jama JW, Launer LJ, Witteman JC, et. al. Dietary antioxidants and cognitive function in a populationbased sample of older persons. The Rotterdam Study. Am J Epidemiol. 1996 Aug 1;144(3):275-80.

130. Perrig WJ, Perrig P, Stahelin HB. The relation between antioxidants and memory performance in the old and very old. J Am Geriatr Soc. 1997 Jun;45(6):718-24.

131. Paleologos M, Cumming RG, Lazarus R. Cohort study of vitamin $C$ intake and cognitive impairment. Am J Epidemiol. 1998 Jul 1;148(1):45-50.

132. Jacob RA. Vitamin C. In: Shils ME, Olson JA, Shike M, Ross AC, eds. Modern Nutrition in Health and Disease. 9th ed. Baltimore, MD: Williams \& Wilkins; 1999.

\section{About the Authors}

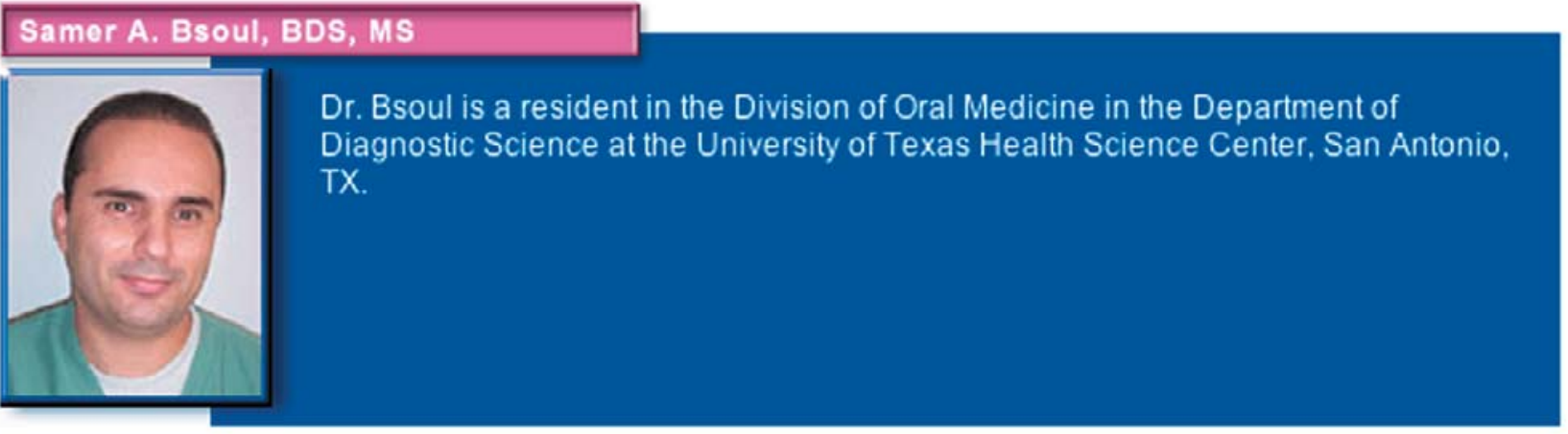

\section{Geza T. Terezhalmy, DDS, MA}

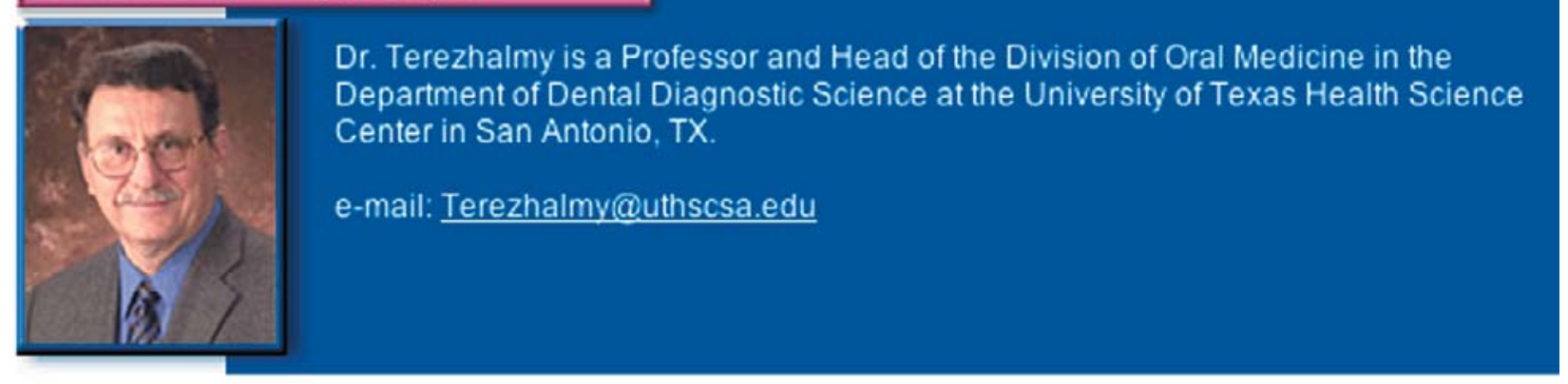

